\title{
Variations in Water Quality from Source to Point of Use in Abeokuta - Nigeria
}

\author{
Adesogan, S.O and Osinfade, S.F
}

\begin{abstract}
Water related diseases are predominant in rural areas of developing. This paper focuses on determination of the factors causing variations in water quality from source of abstraction to the point where water is used.

The approach to the study includes field survey of study area; and identification self-supply systems in these communities. Data collection approach involved the quantitative and the qualitative.

The findings confirm $75 \%$ of samples collected at the source were contaminated with $E$. coli and had high total bacteria count. Groundwater pollution results from industrial activities. $90 \%$ of well users use multiple buckets \& rope to draw from source, of which where the bucket $\&$ rope is being kept on cannot ascertain the hygienic condition of place. $40 \%$ of respondent drink water from the well without noticing ill-health.

It is concluded that the quality of water deteriorates from the source to the point of use and this brings about the variations in water quality.
\end{abstract}

Keywords - Variation, Water Quality, Water Source, Point of Use, Abeokuta - Nigeria.

\section{INTRODUCTION}

Due to the inability of government to provide water which is one of the basic fundamental human need people have resulted to sourcing for water for themselves.

In developing countries, there is inadequate and no dependency on public water supply, people therefore results to source for water themselves hence the birth of self-supply systems. In the quest of this, a large number of people are concerned about the nearest, easiest way of getting water and also the quantity, little attention is paid to the quality of water.

Various reasons have been proposed for the deterioration of water quality between the source and point-of-use (POU). The hygienic condition of the water storage containers and the environment in which these containers are stored are believed to be major factors leading to the deterioration of stored water $[1$, 2, 3 and6].

Self-supply systems is defined as improvements to household or community water supply systems achieved through user investment water treatment, supply construction and up-grading, and rainwater harvesting [5]. They are constructed to serve as alternatives to the erratic and unreliable public water

Adesogan, S.O, Associate Professor, Department of Civil Engineering, University of Ibadan, Nigeria.

Osinfade, S.F, Department of Civil Engineering, University of Ibadan, Nigeria. supply. They also fulfil the two requirements at the household level; to deliver adequate amounts of water to meet consumer consumption requirements and the required amount of water needs to be available 24 hours a day, 365 days a year.

It has been affirmed that the Self-Supply conceptual framework considers incremental improvements to supply (ground or rainwater) and to its quality mainly by owners themselves [4]. Self-supply systems are constructed to serve as alternatives to the erratic and unreliable public water supply. They are constructed and managed by the owner of the landed property (landlords) to meet the water demand of primarily the residents of his property. An example of such a system is a hand dug well. The point at which water is needed is referred to as the point of use or point of consumption. Access to potable and safe drinking water is essential to health, a basic human right and a component of effective policy for health protection. The importance of Water quality therefore cannot be over emphasised. Water quality measures of the suitability of water for a particular use based on selected physical, chemical, and biological characteristics. Safe water prevents the spread of water borne diseases and sanitation related diseases.

\section{THE STUDY AREA}

Abeokuta, the capital of Ogun State in Nigeria is the sub-humid tropical zone of South-western found between latitude $7.5^{\circ} \mathrm{N}$ to $7.20^{\circ} \mathrm{N}$ and longitude $3.17^{\circ} \mathrm{E}$ and $3.27^{\circ} \mathrm{E}$. The city covers a geographical area of $1,256 \mathrm{~km} 2$, which includes Abeokuta North, Abeokuta South and part of Obafemi Owode and Odeda Local Government Area of Ogun State. The research focused on self-supply hand dug wells in the selected township located at Sapon, Itoku, ake, Adatan, and Ilugun the densely populated areas of Abeokuta South Local Government Area of Nigeria.

\section{Methodology}

The research methodology involved water sampling and water quality determination from source to POU. Samples used for analysis of physical and chemical parameter were collected and analysed in accordance with standard practice.

\section{RESULTS}

The results of all the water quality parameters (temperature, $\mathrm{PH}$, electrical conductivity, chloride, nitrate, sulphate, sodium, potassium, calcium hardness) from source to point of use are presented in Table 1. Table 2 represents the descriptive 
statistics of maximum, minimum, mean and standard deviation of the analysed parameters.

\section{A. Discussion}

\section{Physical and Chemical Analysis}

Slight variations in the $\mathrm{PH}$ values of the source water to the point of use, indicates no significant difference in the means of the paired samples. Generally, PH values increased from the well source to POU, this increase can be explained as a result of dissolved oxygen during transport of water from source to POU (Gundry S, et al, 2006)

In Itoku, the highest values of EC must have been attributed to the tie \& dye cottage industry in the area.. Ilugun shows the least values in the amount of chloride in groundwater and Itoku shows the highest in the values of chloride. While Itoku has the highest in value of nitrate and Ilugun shows the least. Similarly, Itoku has the highest level of sulphate and sodium content in the groundwater and Ilugun has the least. A sharp increase in the potassium content of groundwater is seen Adatan well 4 compared to the rest of the location. This is as a result of the characteristics of the type of geologic formation found in the location. Sapon shows the highest value of calcium hardness, this must be an attribute of the type of rock beneath the location.

Wells at Itoku showed considerable increase in EC, chloride, sodium, nitrate, and sulphate content. A high value of the listed parameters confirms the nature of anthropogenic activities in the area having an effect on the water quality. Itoku area of Abeokuta is known for their indigenous activity in tie and dye business. Dyeing is a combined process of bleaching and colouring which generates voluminous quantities of wastewater and in turn causes percolation of waste water which is highly mineralized. The effluents consist of high concentrations of dye chemicals, biochemical oxygen demand, total dissolved solids, sodium, chloride, sulphate, hardness, heavy metals and carcinogenic dye ingredients.

\section{Microbial Analysis}

There was a considerable increase of TCC at POU than at the source and also an increase of E.coli at the POU compared to the source; the result shows that water quality deteriorates over distance and time. Microbiological quality of water at source and point of use declines after collection, as depicted in Ilugun, Adatan, and itoku. The high TCC and E.coli could be attributed to the poor sanitary condition around well area, the presence of anthropogenic activities e.g. washing, cooking, urinating etc. and contamination of bucket and rope. Similarly, temperature of environment can induce the growth of these bacteria. $75 \%$ of samples tested positive with the presence of an indicator (bacteria). The parameters measured are presented in Table 1 shows that variations in water quality deteriorate. There was increasing trend in the values of PH from well source to POU. Other parameters showed increase or decrease at the source or POU. In Ilugun, the values of electrical conductivity, potassium, sodium, nitrate, sulphate, calcium hardness reduced from the source to POU. While the chloride content at the POU is higher than at source. Similarly, at Adatan, the value of electrical conductivity reduced from the source to point of use while the chloride content, potassium, sodium, nitrate, sulphate and calcium hardness are at higher level at POU to that obtained at source. At Itoku, the $\mathrm{PH}, \mathrm{EC}$, sodium, potassium, calcium hardness increased from source to point of use while the chloride, nitrate and sulphate are at source is lower than at POU. Increase in particularly the EC may be due to existence of massive tie \& dye cottage industrial activity at the location. The $\mathrm{PH}, \mathrm{EC}$, sulphate, potassium increases from the source to point of use while the chloride, nitrate, sodium and calcium hardness content at source are lower than at POU in Sapon.

Lastly at Ake, the PH, nitrate and Calcium hardness at higher at the source while sulphate, sodium, potassium measures the same at source and POU. The EC and chloride at source are higher than at POU. 
TABLE I: RAW DATA

\begin{tabular}{|c|c|c|c|c|c|c|c|c|c|c|c|c|}
\hline & \multirow[b]{2}{*}{ WELLS } & \multirow{2}{*}{\begin{tabular}{|l} 
PH \\
SOURCE
\end{tabular}} & \multirow[b]{2}{*}{ POU } & \multirow{2}{*}{$\begin{array}{l}\text { TEMP }\left({ }^{\circ} \mathrm{C}\right) \\
\text { SOURCE }\end{array}$} & \multirow[b]{2}{*}{ POU } & $\mathrm{EC}(\mu \mathrm{S} / \mathrm{cm})$ & \multirow{2}{*}{$\begin{array}{l}\mathrm{Cl}(\mathrm{mg} / \mathrm{l}) \\
\text { SOURCE }\end{array}$} & \multirow[b]{2}{*}{ POU } & \multicolumn{2}{|c|}{$\mathrm{NO}_{3}{ }^{2-}(\mathrm{mg} / \mathrm{l})$} & \multicolumn{2}{|l|}{$\mathrm{SO}_{4}{ }^{2-}(\mathrm{mg} / \mathrm{l})$} \\
\hline & & & & & & SOURCE POU & & & URCE POU & & \begin{tabular}{l|l} 
SOURCE & POL
\end{tabular} & OU \\
\hline \multirow[t]{5}{*}{ ILUGUN } & 1 & 6.93 & 7.115 & 29.1 & 29.4 & \begin{tabular}{|l|l|}
615 & 621 \\
\end{tabular} & 5 & 5 & 6.5 & 5.5 & | 71.945 & 74.525 \\
\hline & 2 & 7.02 & 7.21 & 29.7 & 29.5 & 706 & 5 & 53.5 & 19 & 6.5 & 79.99 & 73.86 \\
\hline & 3 & 7.52 & 7.625 & 29.4 & 29.3 & 592.5 & & 42 & 11 & 8 & 76.805 & 66.14 \\
\hline & 4 & 7.33 & 7.54 & 29.4 & 29.4 & 686 & 55 & 58.5 & 12.5 & 24.5 & 86.33 & 93.885 \\
\hline & 5 & 7.32 & 7.45 & 29.5 & 29.5 & 427 & 22. & 66 & 22.5 & 17.5 & 75.665 & 74.345 \\
\hline ADATAN & 1 & 7.41 & 8.37 & 29.7 & 29.8 & 788.5 & 75. & 65.5 & 16 & 16 & 87.05 & 92.63 \\
\hline & 2 & 7.15 & 7.405 & 29.7 & 29.8 & 962 & 115 & 125 & 14.5 & 14 & 76.475 & 80.31 \\
\hline & 3 & 6.86 & 7.15 & 29.8 & 29.7 & 800.5 & 5 & 121 & 17.5 & 36.5 & 86.955 & 26.93 \\
\hline & 4 & 6.95 & 7.04 & 29.5 & 29.8 & 983.5 & 5 & 58.5 & 8 & 13.5 & 82.95 & 93.385 \\
\hline & 5 & 6.975 & 7.03 & 29.9 & 29.9 & 834.5 & 77. & 96.5 & 22 & 24.5 & 58.395 & 58.05 \\
\hline & & & & & & & & & & & & \\
\hline ITOKU & 1 & 7.47 & 7.74 & 28.9 & 28.9 & 1128.5 & 193. & 145 & 25.5 & 27.5 & 101.76 & 101.295 \\
\hline & 2 & 7.525 & 7.8 & 28.9 & 28.8 & 1205 & 159. & 159 & 43 & 50.5 & 78.88 & 84.195 \\
\hline & 3 & 8.135 & 8.08 & 28.9 & 28.8 & 1245 & 16 & 0 & 126 & 15.5 & 103.7 & 95.5 \\
\hline & 4 & 8.095 & 7.925 & 28.9 & 28.9 & 1032 & 130. & 128.5 & 32.5 & 24.5 & 89.67 & 87.75 \\
\hline & 5 & 8.05 & 8.065 & 28.9 & 29.1 & 1483.5 & 21 & 256.5 & 46.5 & 33.5 & 101.295 & 105.34 \\
\hline & & & & & & & & & & & & \\
\hline SAPON & 1. & 7.34 & 7.26 & 29.2 & 29.1 & 1286 & 17 & 174.5 & 99.5 & 24 & 112.41 & 94.85 \\
\hline & 2 & 7.275 & 7.345 & 29 & 29.1 & 912 & 105. & 105.5 & 21 & 29 & 68.215 & 74.04 \\
\hline & 3 & 7.33 & 8.035 & 29.1 & 29.2 & 994.5 & 10 & 114.5 & 29 & 31.5 & 68.05 & 78.54 \\
\hline & 4 & 7.35 & 7.45 & 29.2 & 29.1 & 855 & 105. & 95 & 24.5 & 21.5 & 68.855 & 69.045 \\
\hline & 5 & 7.26 & 7.31 & 29.1 & 29.2 & 896 & 10 & 103.5 & 12 & 30 & 62.8 & 73.865 \\
\hline & & & & & & & & & & & & \\
\hline AKE & 1 & 7.175 & 7.36 & 29.5 & 28.9 & 439 & 39. & 46.5 & 1.985 & 1.85 & 60.47 & 63.55 \\
\hline & 2 & 7.27 & 7.35 & 29.3 & 29.3 & 532.5 & 57. & 53.5 & 1.975 & 1.625 & 67.25 & 69.045 \\
\hline & 3 & 7.28 & 7.475 & 29.2 & 29.3 & 567.5 & 5 & 50.5 & 7.395 & 3.78 & 64.755 & 60.81 \\
\hline & 4 & 8.17 & 8.265 & 29.2 & 29.2 & 919 & 94. & 97.5 & 3.965 & 4.32 & 81.95 & 77.75 \\
\hline & 5 & 8.075 & 8.095 & 29.1 & 29.1 & 632 & 49. & 50 & 3.43 & 2.885 & 70.325 & 70.33 \\
\hline & & $\mathrm{Na}^{+}(\mathrm{mg} / \mathrm{l})$ & & $\mathrm{K}^{+}(\mathrm{mg} / \mathrm{l})$ & & $\mathrm{CaCO}_{3}(\mathrm{mg} / \mathrm{l})$ & & CC(cfu/100ml) & & E.COL & $\mathrm{L}(\mathrm{cfu} / 100 \mathrm{ml})$ & \\
\hline & WELLS & SOURCE & POU & SOURCE & POU & SOURCE & $\mathrm{OU}$ & OURCE & POU & SOUR & & POU \\
\hline ILUGUN & 1 & 5.5 & 6.3 & $\quad 16.5$ & 13.5 & 125 & 123 & 97000 & D) 27100 & & o & $\begin{array}{l}0 \quad 400 \\
0\end{array}$ \\
\hline & 2 & 8.5 & 6.5 & 47.5 & 24.5 & 132 & 123.5 & 180 & 17400 & & o & 600 \\
\hline & 3 & 8 & 6 & 24 & 11.5 & 109 & 105 & 19500 & 4950 & & 700 & c \\
\hline & 4 & 11 & 8.5 & 12.5 & 13.5 & 154 & 161 & 4000 & 796000 & & 0 & 1200 \\
\hline & 5 & 4 & 4 & 14.5 & 5.5 & 86.5 & 84 & 1250000 & 17300 & & 1800 & $\mathrm{c}$ \\
\hline & & & & & & & & & & & & \\
\hline ADATAN & 1 & 7 & 6.5 & 18.5 & 30.5 & 155 & 161 & 8700 & 1200000 & & o & 1600 \\
\hline & 2 & 13.5 & 9 & 31 & 52 & 92.5 & 84 & 26700 & 18000 & & o & 4000 \\
\hline & 3 & 9.5 & 3.5 & 35 & 5.5 & 67.5 & 41 & 24000 & 28800 & & 3150 & c \\
\hline & 4 & 11.5 & 8 & 57.5 & 33 & 131 & 137.5 & 27900 & 4500000 & & o & 1300 \\
\hline & 5 & 6.5 & 7 & 26.5 & 34 & 104.5 & 119 & 56000 & 15800 & & 1700 & c \\
\hline & & & & & & & & & & & & \\
\hline ITOKU & 1 & 21 & 21 & 24 & 24 & 127 & 122.5 & 300 & 160 & & 0 & 900 \\
\hline & 2 & 21 & 22 & 24 & 24 & 81 & 95 & 130 & 24000 & & 0 & 1800 \\
\hline & 3 & 24 & 25 & 26 & 26 & 84.5 & 109 & 800 & 28900 & & o & 1200 \\
\hline & 4. & 16.5 & 18.5 & 18.5 & 19.5 & 88.5 & 98.5 & 27000 & 450000 & & 9600 & 350000 \\
\hline & 5 & 29 & 28 & 28.5 & 29 & 103.5 & 137.5 & 560000 & 900000 & & 560000 & 85000000 \\
\hline & & & & & & & & & & & & \\
\hline SAPON & 1 & 24.5 & 24 & 25 & 25.5 & 190 & 172.5 & 25900 & 500000 & & 2200 & 13000 \\
\hline & 2 & 18.5 & 18 & 19 & 19.5 & 161 & 145.5 & 450000 & 1100 & & 12000 & 0 \\
\hline & 3 & 19 & 17.5 & 20.5 & 20.5 & 154.5 & 155.5 & 3000 & 6800 & & o & p \\
\hline & 4 & 17 & 17 & 18 & 19.5 & 154 & 141 & 1300 & 3700 & & 0 & ) \\
\hline & 5 & 16 & 15 & 17 & 16.5 & 141 & 151 & 3700 & 15300 & & o & 400 \\
\hline & & & & & & & & & & & & \\
\hline AKE & 1 & 12 & 13.5 & 13 & 13 & 78 & 81 & 1100 & 2200 & & o & ? \\
\hline & 2 & 12 & 14 & 15 & 15 & 68 & 66 & 1000 & 3200 & & o & ) \\
\hline & 3 & 12.5 & 12.5 & 13 & 13 & 91 & 79.5 & 4800 & 6900 & & 0 & ) \\
\hline & 4 & 17.5 & 19 & 19.5 & 20.5 & 147 & 121.5 & 3500 & 1900 & & 0 & ) \\
\hline & 5 & 11 & 11 & 12 & 12 & 126.5 & 90 & 1200 & 1000 & & o & 0 \\
\hline
\end{tabular}




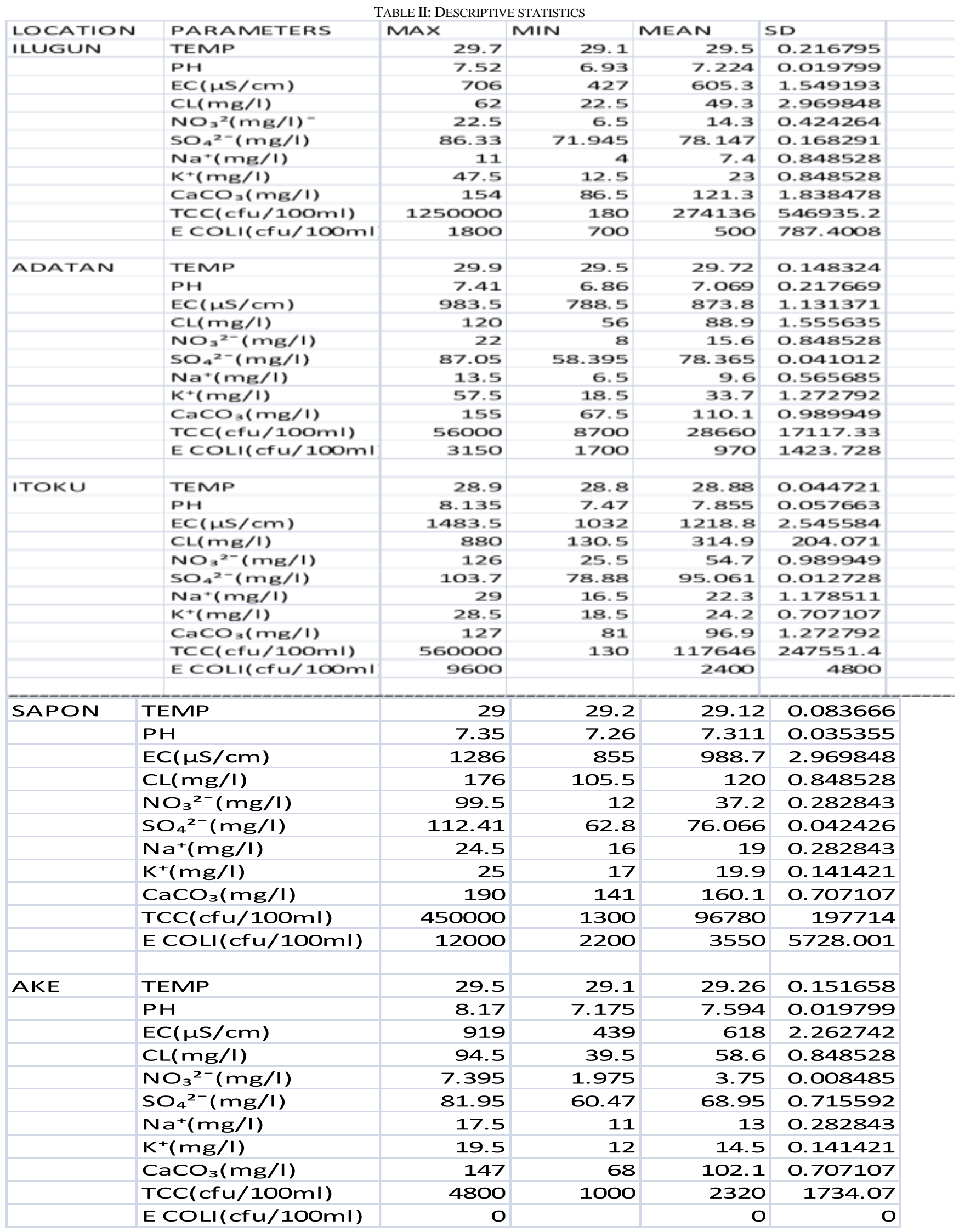




\section{CONCLUSION}

It is evident from this research that the quality of water deteriorates from the source to the point of use and this brings about the variations in water quality. Itoku area was distinct with high values in the water quality parameters measured compared with the other locations; this shows a gradual contamination in the groundwater in the area as a result of the tie $\&$ dye business. Also, the findings confirm $75 \%$ of samples collected at the source were contaminated with E. coli and had high total bacteria count but more at POU.

\section{RECOMMENDATIONS}

1. A minimum distance of $30 \mathrm{~m}$ is advised from pollution sources such as sewerage systems, burial site, gutters and pit privy to well.

2. The use of a dedicated bailer is compulsory to prevent introduction of contaminants into the well. A waterproof well cover is important especially during rainy season

3. Water treatment practices should be encouraged at household level, at least boiling methods.

\section{REFERENCES}

[1] Gundry, S; Wright, J and Conroy, R (2004): “A systematic review of the health outcomes related to household water quality in develop $\neg$ ing countries." J. Water and health 2 (1) 1-13. https://doi.org/10.2166/wh.2004.0001

[2] Jagals, P; Bokako, TC and Grabow Wok (1999): “Changing con`sumer water use patterns and their effect on microbiological water quality as a result of an engineering intervention". Water sa 25 (3) 297-300.

[3] Jagals, P: Nala, NP; Tsubane TJ; Moabi, M and Motaung KC (2004): "Measuring changes in water-related and hygiene practices by developing community households". Water sci. Technol. 50 (1) 91-97. https://doi.org/10.2166/wst.2004.0027

[4] Sally Sutton (2007): Rural household investment in water supply. Proposal for study of potential for Self Supply in Ethiopia, preparatory to large Scale Implementation End user affordable Steps Consultancy report prepared for rwsn/wsp.

[5] Sutton, s. (2009). An introduction to self-supply: putting the user first, wsp field Note: rural water supply series. 